\title{
Correction to: Dental vulnerability scale in primary health care: evidence of content and structure internal validity
}

Danielle da Costa Palacio ${ }^{1,2^{*}}$ (D) Flavio Rebustini ${ }^{3}$, Daniele Boina de Oliveira ${ }^{1}$, João Peres Neto ${ }^{1}$, Wander Barbieri ${ }^{1}$, Thais Paragis Sanchez ', Ana Carolina Cintra Nunes Mafra', Daiana Bonfim', Camila Nascimento Monteiro', Valmir Vanderlei Gomes Filho', Danielle Viana Ribeiro ${ }^{1}$, Leandro Marsico Loschiavo', João Luiz Miraglia ${ }^{1}$ and Antonio Carlos Pereira ${ }^{2}$

\section{Correction to: BMC Oral Health (2021) 21:421} https://doi.org/10.1186/s12903-021-01742-6

After publication of the original article [1], the authors identified an error in the authors' names of Danielle da Costa Palacio and Camila Nascimento Monteiro.

The incorrect authors' names are:

Danielle da Costa: given name.

da Palacio: family name.

Camila Monteiro: given name.

Nascimento: family name.

The correct authors' names are:

Danielle: given name.

da Costa Palacio: family name.
Camila: given name.

Nascimento Monteiro: family name.

The author group has been updated above and the original article [1] has been corrected.

\footnotetext{
Author details

${ }^{1}$ Hospital Israelita Albert Einstein, Av. Albert Einstein 627, São Paulo, SP, Brazil. ${ }^{2}$ Faculdade de Odontologia de Piracicaba, Universidade Estadual de Campinas, Av. Limeira, 901 - Areião, Piracicaba, SP, Brazil. ${ }^{3}$ Ciências e Humanidades - Rua Arlindo Béttio, Universidade de São Paulo - Escola de Artes, 1000 - Ermelino Matarazzo, São Paulo, SP, Brazil.
}

Published online: 09 September 2021

\section{Reference}

1. Palacio, et al. BMC Oral Health. 2021;21:421. https://doi.org/10.1186/ s12903-021-01742-6.

\section{Publisher's Note}

Springer Nature remains neutral with regard to jurisdictional claims in published maps and institutional affiliations.

The original article can be found online at https://doi.org/10.1186/s12903021-01742-6.

\footnotetext{
*Correspondence: daniellepalacio@yahoo.com.br

${ }^{1}$ Hospital Israelita Albert Einstein, Av. Albert Einstein 627, São Paulo, SP,

Brazil

Full list of author information is available at the end of the article
} original author(s) and the source, provide a link to the Creative Commons licence, and indicate if changes were made. The images or other third party material in this article are included in the article's Creative Commons licence, unless indicated otherwise in a credit line to the material. If material is not included in the article's Creative Commons licence and your intended use is not permitted by statutory regulation or exceeds the permitted use, you will need to obtain permission directly from the copyright holder. To view a copy of this licence, visit http://creativecommons.org/licenses/by/4.0/. The Creative Commons Public Domain Dedication waiver (http://creativecommons.org/publicdomain/zero/1.0/) applies to the data made available in this article, unless otherwise stated in a credit line to the data. 